\title{
Factors associated with mortality in acute subdural hematoma: Is decompressive craniectomy effective?
}

\author{
İlhan Yılmaz, M.D., ${ }^{1}$ D Devrimsel Harika Ertem, M.D., ${ }^{2}$ @ Mustafa Kılıç, M.D., ${ }^{1}$

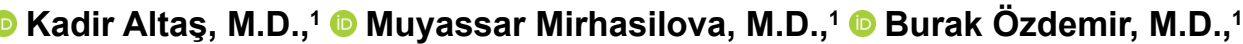 \\ (1) Osman Tanrıverdi, M.D., ${ }^{3}$ (1) Adem Yılmaz, M.D. ${ }^{1}$
}

\begin{abstract}
${ }^{1}$ Department of Neurosurgery, University of Health Sciences, Şişli Hamidiye Etfal Training and Research Hospital, İstanbul-Turkey ${ }^{2}$ Department of Neurology, University of Health Sciences, Şişli Hamidiye Etfal Training and Research Hospital, İstanbul-Turkey ${ }^{3}$ Department of Neurosurgery, University of Health Sciences, Bakırköy Training and Research Hospital For Neurology, Neurosurgery and Psychiatry, İstanbul-Turkey
\end{abstract}

\begin{abstract}
BACKGROUND: Despite rapid diagnosis and aggressive neurosurgical intervention, acute subdural hematoma (ASDH) is a severe type of head injury that can result in high morbidity and mortality. Although surgical procedures, such as craniotomy and decompressive craniectomy (DC), can be effective, the preferred approach for treating an ASDH remains controversial. The aim of this report was to evaluate factors associated with mortality in patients with ASDH and determinants of outcome in those with ASDH who underwent DC.
\end{abstract}

METHODS: The demographic details and clinical and radiological characteristics of a total of 93 patients with ASDH who underwent DC during a 60-month period from 2012 to 2017 were evaluated to determine the effect on mortality and any association with the Glasgow Coma Scale (GCS) score recorded on arrival.

RESULTS: Sixty-five male and 28 female subjects with a mean age of $59.82 \pm 19.49$ years (range: $16-88$ years) were included in the study. Sixteen patients $(17.2 \%)$ died following the surgery. Older age $(p=0.007)$ and lower GCS scores $(p=0.022)$ were statistically significantly associated with the mortality rate. The mean hematoma thickness was $15.46 \pm 5.73 \mathrm{~mm}$, and the mean midline shift was $9.90 \pm 4.84 \mathrm{~mm}$. The mortality rate was positively correlated with an excessive midline shift $(p=0.01 \mathrm{I} ; r=0.262)$ and age $(p=0.022$; $r=0.237$ ) in patients with ADSH. A midline shift of $\geq 10 \mathrm{~mm}$ and a hematoma thickness of $\geq 15 \mathrm{~mm}$ was significantly associated with mortality ( $p=0.014 ; p=0.039$ ). The etiology of the trauma; comorbidities of subarachnoid, epidural, or intracranial hemorrhage; compression fractures; or contusions were not significantly correlated.

CONCLUSION: The results indicated that there was a higher mortality rate among older patients and those with a GCS score of $<6$ on arrival. A midline shift of $\geq 10 \mathrm{~mm}$ and a hematoma thickness of $\geq 15 \mathrm{~mm}$ were significantly related to mortality. Our study supports the conclusion that DC may help prevent further midline shift and be associated with a lower mortality rate compared with a craniotomy.

Keywords: Acute subdural hematoma; decompressive craniectomy; mortality; outcome.

\section{INTRODUCTION}

Acute subdural hematoma (ASDH) is diagnosed in approximately one-third of patients with severe traumatic brain injury, and it leads to serious public health, social, and economic concerns. Because of its complicated pathophysiology, ASDH is associated with high morbidity and mortality rates. It is a space-occupying lesion that causes an increased

Cite this article as: Yılmaz İ, Ertem DH, Kılıç M, Altaş K, Mirhasilova M, Özdemir B, et al. Factors associated with mortality in acute subdural hematoma: Is decompressive craniectomy effective? Ulus Travma Acil Cerrahi Derg 2019;25:147-153.

Address for correspondence: Devrimsel Harika Ertem, M.D.

SBÜ Şişli Hamidiye Etfal Eğitim ve Araştırma Hastanesi, Nöroloji Kliniği, İstanbul, Turkey

Tel: +90 212 - 5436565 E-mail: hkaozhan@gmail.com

Ulus Travma Acil Cerrahi Derg 2019;25(2):147-153 DOI: 10.5505/tjtes.2018.48079 Submitted: 06.08.2018 Accepted: 23.09.2018 Online: 10.10.2018

Copyright 2018 Turkish Association of Trauma and Emergency Surgery 
intracranial pressure and is modified by cerebral blood flow changes, coagulopathy, and delayed hematomas. ${ }^{[1,2]}$ To minimize secondary brain damage, ASDH with brain compression and herniation should be urgently evacuated via craniotomy with or without decompressive craniectomy (DC). ${ }^{[3]}$

Mortality due to ASDH is affected by many variables. Although an effective surgical technique has not been well established yet, DC is among the most preferred surgical procedures for the treatment of patients with severe traumatic brain injury to prevent intracranial hypertension caused by cerebral edema. ${ }^{[4-6]}$ DC helps in controlling of increased intracranial pressure and preventing disturbed cerebral blood flow and edema caused by vasoparesis to maintain the metabolism of the injured brain. ${ }^{[7]}$

Previous studies have reported that the mortality rate was higher in patients with ASDH with lower Glasgow Coma Scale (GCS) scores, a greater hematoma thickness, an excessive midline shift, and in those who were younger. ${ }^{[1,8-10]}$ Furthermore, some studies indicate a higher mortality rate in patients with additional traumatic lesions, particularly in those having experienced out-of-vehicle traffic accidents. ${ }^{[8,11,12]}$ Although DC has become more popular in recent years, its use has not been generally accepted yet. Although the GCS scores, age, and neurological examination and neuroimaging study results are strongly correlated with the outcome, the role of these factors has not yet been clearly defined. ${ }^{[I]}$ In the current study, we retrospectively reviewed 93 consecutive patients with ASDH to identify and predict the preoperative clinical prognostic factors influencing mortality and to assess the correlation with the GCS score and demographic, clinical, and radiological characteristics.

\section{MATERIALS AND METHODS}

This retrospective cross-sectional study was approved by the ethics committee of University of Health Sciences, Sisli Hamidiye Etfal Training and Research Hospital and was performed in accordance with the Declaration of Helsinki. We reviewed the records of 93 patients having undergone surgical intervention for ASDH, who were admitted within $3 \mathrm{~h}$ of injury to the emergency room during a 60 -month period from 2012 to 2017 . We excluded the data of 24 patients with a GCS score of 3, who had died immediately and 26 patients with ASDH who were treated conservatively. All patients were treated according to the guidelines for the management of patients with severe traumatic brain injury, third edition. [13] The patients' demographic characteristics (age, sex), information on trauma, the GCS score on admission, brain computed tomography (CT) findings, neurological examinations, and postoperative complications were recorded.

The unilateral, bilateral, or bifrontal DC using the usual techniques was performed based on the presence of the lesion or diffuse brain swelling. After the duraplasty, using a dura graft that was excised from the galea, the temporal muscle was sutured loosely above the dura. Following the surgery, all patients were followed up in the neurosurgical intensive care unit for postoperative monitoring. A control brain CT was performed in all patients after the surgery. The patients were transferred to the ward after their vital signs were stable.

\section{Statistical Analysis}

In this study, all statistical tests were performed with the Statistical Package for the Social Sciences (SPSS) 23.0 software (IBM Corp., Chicago, USA). Descriptive statistics (mean, standard deviation, frequency, and percentage) were used for the demographic and clinical characteristics. Categorical data were compared using the chi-squared test or Fisher's exact test. A multivariate logistic regression analysis was performed for the in-hospital mortality to determine the clinical predictors. A p-value of $<0.05$ was considered to be statistically significant.

\section{RESULTS}

During the 5-year period, 93 patients were treated for ASDH due to head injuries. These injuries were treated with DC, which was performed at our neurosurgery department. The mean age of the subjects was $59.82 \pm 19.49$ years (range, 16-88 years). There were 65 male patients. The in-hospital mortality rate was $17.2 \%$. Trauma due to fall (46.2\%) was the most common etiology, and the mean time from the emer-

Table I. Demographic and clinical characteristics of patients with ASDH undergoing decompressive craniectomy

\begin{tabular}{ll}
\hline Characteristics & Number of patients \\
\hline Age & $59.82 \pm 19.49$ \\
Sex & Male/female: $65 / 28$ \\
GCS scores & GCS 4-5: $n=23(24.7 \%)$ \\
& GCS 6-10: $n=22(23.7 \%)$ \\
& GCS II-15: $n=48(51.6 \%)$ \\
Etiology of trauma & Car crashes: $n=19(23.7 \%)$ \\
& Fall: $n=43(46.2 \%)$ \\
Additional pathology & Other: $n=31$ \\
& Epidural hematoma: $n=15$ \\
& Subarachnoid hemorrhage: $n=10$ \\
& Compression fracture: $n=7$ \\
Thickness (mm) of SDH, & Intracranial hematoma: $n=5$ \\
mean $\pm S D$ & Contusion: $n=3$ \\
Midline shift $(\mathrm{mm})$, mean $\pm S D$ & $9.90 \pm 4.84$ mm \\
Mortality & I6 (I7.2\%) \\
\hline
\end{tabular}

GCS: Glasgow Coma Scale; SDH: Subdural hematoma; SD: Standard deviation. 
Table 2. Association analysis of mortality and demographic and clinical variables

\begin{tabular}{|c|c|c|c|}
\hline Variables & Groups within the variable & Number of patient $(n)$ & $\mathbf{p}^{*}$ \\
\hline \multirow[t]{2}{*}{ GCS groups of patients ${ }^{* * *}$} & Group I: GCS 4-5 & GI:23 & $0.022^{* *}$ \\
\hline & Group 2: GCS 6-9 and GCS 10-16 & G2:70 & \\
\hline \multirow[t]{2}{*}{ Age groups } & Group I: Younger patients $(\leq 60)$ & GI:46 & $0.007^{* *}$ \\
\hline & Group 2: Older patients (>60) & $\mathrm{G} 2: 47$ & \\
\hline \multirow[t]{2}{*}{ Sex groups } & Group I: Male & GI:65 & 0.191 \\
\hline & Group 2: Female & $\mathrm{G} 2: 28$ & \\
\hline \multirow[t]{3}{*}{ Etiology of trauma } & Group I: Fall & GI:43 & 0.926 \\
\hline & Group 2: Car accident & G2:19 & \\
\hline & Group 3: Other & G3:31 & \\
\hline \multirow[t]{2}{*}{ Subarachnoid hemorrhage } & Group I: Yes & GI:I0 & 0.201 \\
\hline & Group 2: No & $\mathrm{G} 2: 83$ & \\
\hline \multirow[t]{2}{*}{ Epidural hematoma } & Group I: Yes & GI:I5 & 0.454 \\
\hline & Group 2: No & $\mathrm{G} 2: 78$ & \\
\hline \multirow[t]{2}{*}{ Intracerebral hematoma } & Group I: Yes & GI:5 & \\
\hline & Group 2: No & G2:88 & 0.380 \\
\hline \multirow[t]{2}{*}{ Contusion } & Group I: Yes & GI:3 & 0.564 \\
\hline & Group 2: No & $\mathrm{G} 2: 90$ & \\
\hline \multirow[t]{2}{*}{ Compression fracture } & Group I: Yes & GI:7 & 0.600 \\
\hline & Group 2: No & $\mathrm{G} 2: 86$ & \\
\hline
\end{tabular}

"Chi-squared test or Fisher's exact test was applied for the association analysis. "There is a relation b/w variables at the $5 \%$ level of statistical significance. GCS: Glasgow Coma Scale.

gency department admission to surgical intervention was 3 h. Forty-three patients (46.2\%) had co-existing pathologies, such as epidural hematoma, traumatic subarachnoid hem-

Table 3. Correlation analysis of mortality and age, the hematoma thickness, and midline shift

\begin{tabular}{lcc}
\hline Variables & Correlation Coefficient $^{*}$ & $\mathbf{p}$ \\
\hline Age & 0.262 & $0.011^{* *}$ \\
Thickness & 0.156 & 0.136 \\
Midline shift & 0.237 & $0.022^{* *}$ \\
\hline
\end{tabular}

"Spearman's rho correlation coefficient. "There is a relation b/w variables at the $5 \%$ level of statistical significance. orrhage, compression fracture, and contusion. None of the patients had a history of alcohol abuse. Four patients had a history of multiple falls. Three patients were treated with anti-aggregants and/or anticoagulants. Intracranial pressure (ICP) monitoring was not done because of the acute surgical operation.

The mean hematoma thickness was $15.46 \pm 5.73 \mathrm{~mm}$. The ASDH thickness was not correlated with the GCS score $(p=0.136)$. There was no statistically significant relationship between the mean ASDH thickness and the mortality rate. The mean midline hematoma shift was $9.90 \pm 4.84 \mathrm{~mm}$. The midline shift was correlated with the GCS score and mortality rate $(p=0.022)$. The demographic, radiologic, and clinical characteristics of the patients are given in Table I.

Table 4. Association analysis of the hematoma thickness and midline shift $(\mathrm{mm})$ on the mortality rate

\begin{tabular}{llcl}
\hline Variables & Groups within the variable & Number of patients (n) \\
\hline Midline shift $(10 \mathrm{~mm})$ & Group I: Shift $<10 \mathrm{~mm}$ & GI:37 \\
& Group 2: Shift $\geq 10 \mathrm{~mm}$ & G2:56 & P \\
Thickness $(15 \mathrm{~mm})$ & Group I: Thickness $<15 \mathrm{~mm}$ & GI:39 \\
& Group 2: Thickness $\geq 15 \mathrm{~mm}$ & G2:54 \\
\hline
\end{tabular}

${ }^{*}$ Chi-squared test. 
Table 5. Results of the logistic regression analysis

\begin{tabular}{lccccc}
\hline Predictor variable & Beta coefficient & Standard error & Wald & Significance (p) & Variable values \\
\hline GCS scores 4-5 & -1.72 & 0.66 & 6.91 & 0.009 & 0: Other patients \\
& & & & 0.110 & I: Patients with a low GCS (4-5) \\
Shift & & & & 0.65 & - \\
Age & -0.10 & 0.21 & 6.89 & 0.009 & The model constant \\
Constant & -0.56 & 1.74 & 15.54 & 0.000 & - \\
\hline
\end{tabular}

"Variable is eliminated from the logistic regression model due to an insignificant beta coefficient.

The most common complication of the surgery was the development of meningitis, which occurred in 5 (15\%) patients. Sixteen (17.2\%) patients died after surgery. An improvement in the GCS scores was noted in 68 patients at the follow-up during the hospital stay.

The analysis of association between mortality and demographic and clinical characteristics is given in Table 2 . The administration of blood thinners did not show a statistically significant association with an increased risk of mortality $(p=0.07 \mathrm{I})$. Neither additional pathology nor etiology of trauma had a significant relationship with the mortality rate.

The mortality rate was positively correlated with an excessive midline shift $(p=0.01 \mathrm{I}, r=0.262)$ and age $(p=0.022, r=0.237)$ (Table 3). Patients with the midline shift $\geq 10 \mathrm{~mm}$ and patients with a hematoma thickness $\geq 15 \mathrm{~mm}$ had a significant association with the mortality rate $(p=0.014, p=0.039)$. An association analysis of the hematoma thickness and midline shift $(\mathrm{mm})$ on the mortality rate was presented in Table 4 . We developed a multiple logistic regression model to assess the relationship between the mortality rate and clinical variables. Among the used variables, the GCS scores lower than 6 and older age were associated with greater odds of mortality in the logistic regression analyses (Table 5).

\section{Illustrative Cases}

Figure I shows the serial cranial axial CT scans of a 22-year-
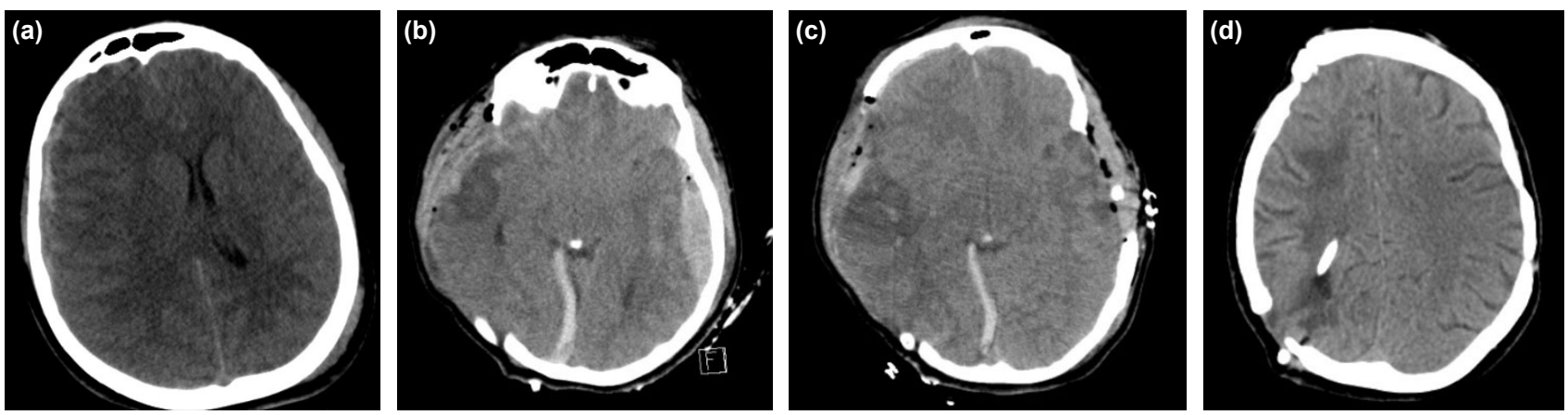

Figure 1. (a) Cranial axial CT scan of a 22-year-old female patient with right-sided ASDH and a midline shift. (b and c) A right DC followed by a left craniectomy was performed. (d) The patient required a ventriculo-peritoneal shunt due to hydrocephalus.
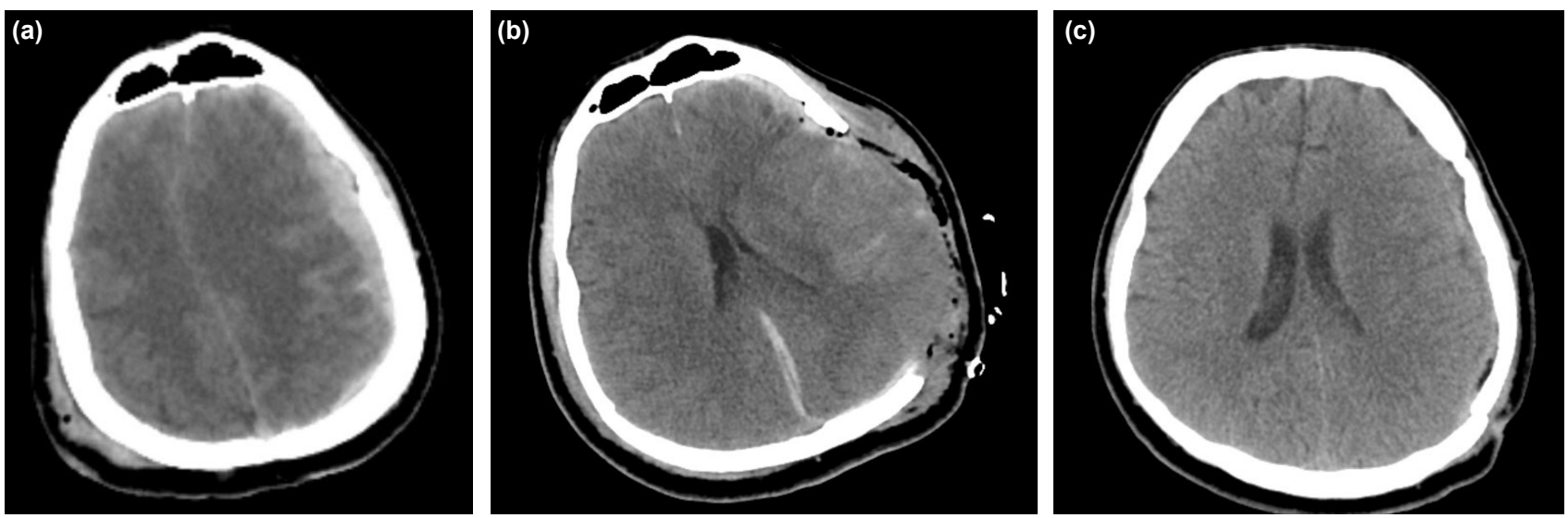

Figure 2. (a-c) Show the serial cranial axial CT scan of a 35-year-old male patient with left-sided ASDH, traumatic subarachnoid haemorrhage with midline shift. Cranioplasty was performed after 3 months. 

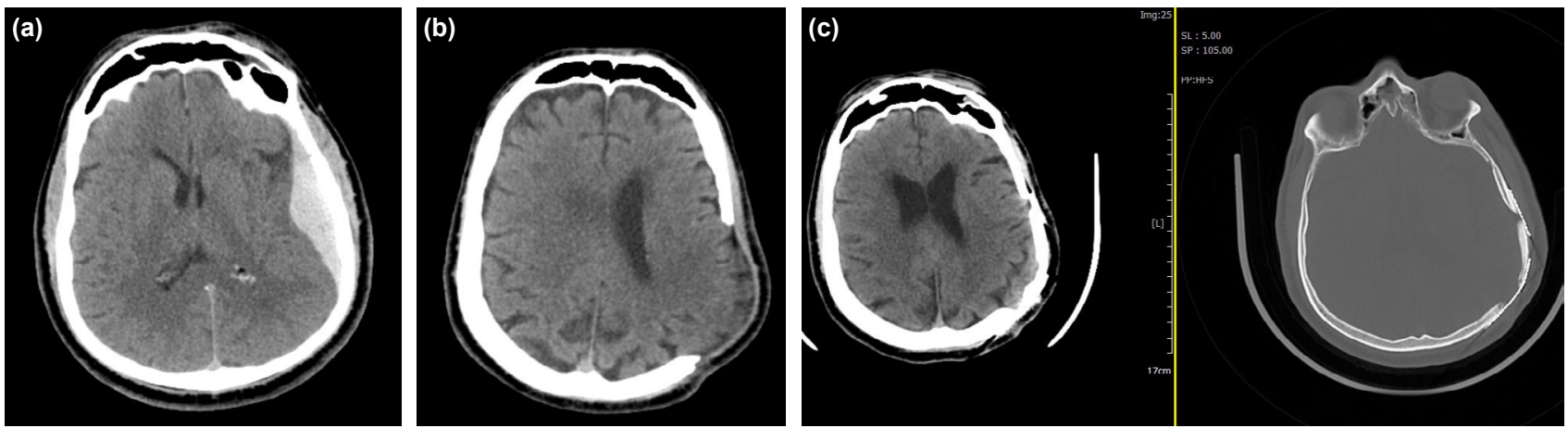

Figure 3. (a-c) Show cranial axial CT scan of a 54-year-old male patient with left-sided ASDH. Cranioplasty was performed after 3 months.

old female patient who developed ASDH due to experiencing a car crash and who had a GCS score of 4 . A right DC followed by a left craniectomy was performed. The patient required a ventriculo-peritoneal shunt due to hydrocephalus. She was neurologically intact by the third month following discharge.

Figure 2 shows the serial cranial axial CT scan of a 35-yearold male patient with left-sided ASDH and traumatic subarachnoid hemorrhage with a midline shift. Cranioplasty was performed after 3 months.

Figure 3 shows the cranial axial CT scan of a 54-year-old male patient with left-sided ASDH. Cranioplasty was performed after 3 months.

\section{DISCUSSION}

This study aimed to demonstrate the outcomes pertaining to the management of ASDH after DC and to assess which parameters were significant in predicting the patient mortality. Our logistic regression analysis demonstrated that the older age and lower GCS scores were related to higher mortality rates. Moreover, our results indicate that the presence of an additional pathology and etiology of trauma had no significant relationship with the mortality rate. Patents with the midline shift $\geq 10 \mathrm{~mm}$ and patients with a hematoma thickness $\geq 15 \mathrm{~mm}$ showed a significant correlation with the mortality rate. Furthermore, the mortality rate was positively correlated with age and the midline shift. In this study, all patients underwent hematoma evacuation via DC immediately upon admission. Different surgical techniques, namely, twist drill trephination/craniostomy procedures, burr hole trephination, craniotomy with or without dural grafting, and subtemporal DC, have been used for the evacuation of an ASDH. ${ }^{[14]}$ Although the indications for the operation methods have not been clearly established in ASDH, there are limited studies investigating the effect of procedure types on outcomes. The choice between craniotomy and DC techniques may depend on the neurosurgeon's expertise and training. A progression in the neurological deficit (altered mental status, pupillary asymmetry, etc.) and radiological changes over time are other important factors considered to decide the type of surgical treatment. Similar to our department, some centers treat all subdural hematomas (SDHs) with DCs ${ }^{[15,16]}$ to prevent herniation from compressing the brain and brainstem.

In a study analyzing the association of surgical methods and outcomes of ASDH patients, Vilcinis et al. ${ }^{[2]}$ recently reported a higher mortality rate and worse discharge outcomes for patients with ASDH who had undergone DC, independent of clinical severity compared with the rate and outcomes for those who had undergone osteoplastic craniotomy. The authors explained that these worse outcomes in DC patients were caused by a greater brain injury severity. Similar to previous studies, they preferred DC as the surgical method for younger patients presenting with severe brain damage. ${ }^{[17,18]}$ In our study, we did not divide the patients into groups according to their ages. Furthermore, the mortality rate was found to be lower in the younger subjects in our sample. Our findings demonstrate that younger patients also benefit from this procedure. According to our experience, enlarging the craniectomy may help in controlling the intracranial pressure and brain damage and decrease the mortality and morbidity rates. Koç et al. ${ }^{[19]}$ reported on $1 / 3$ patients who underwent craniotomy for traumatic ASDH; these patients were followed up for 3 months after admission and showed a mortality rate of $60 \%$. Leitgeb et al. ${ }^{[1]}$ demonstrated a higher mortality rate and found that nonoperative management was associated with a significantly higher mortality rate. Our mortality rate was only $18 \%$; thus, we can conclude that immediate and adequate DC procedures prevent symptoms of brain damage, such as brain swelling, neurological deterioration, infarction, and acute edema, following a massive infarction. In this study, we aimed to share our DC experience in patients with ASDH to identify and predict the preoperative clinical prognostic factors on the mortality rate. Our results demonstrate that performing DC among older individuals and lower GCS scores are associated with a higher mortality rate. In addition, it should be kept in mind that patients with the midline shift $\geq 10 \mathrm{~mm}$ and a hematoma thickness $\geq 15 \mathrm{~mm}$ on the radiological evaluation are associated with higher mortality rates.

We subsequently investigated the clinical prognostic indicators associated with patient outcomes. Complications re- 
lated to DC include brain parenchyma herniation, hygroma and hydrocephalus, contralateral subdural hematoma, intraparenchymal hemorrhage, infection, and brain edema. ${ }^{[20]}$ Meningitis was the most common complication reported in our series. Despite the importance of the time of surgery in ASDH, research on this aspect is limited. Shabani et al. ${ }^{[2]}$ reported that neurologic deterioration occurred within the first $24 \mathrm{~h}$ in $70 \%$ of delayed ASDH patients. Wilberger et al. ${ }^{[22]}$ demonstrated that the mortality in DC patients operated on within $4 \mathrm{~h}$ of injury was $59 \%$ and that the mortality in patients operated on more than $4 \mathrm{~h}$ after injury was $69 \%$. In our patients, the mean time between injury and operation did not show a statistically significant relationship with mortality. Although these findings suggest that the time of surgical intervention for SDH does not primarily affect the mortality, to the best of our knowledge, early intervention is necessary to prevent a substantial impact of brain injury regardless of the GCS score. Similar to our results, comorbid intracranial and extracranial lesions have been reported in larger series to occur in $47 \%-57 \%$ of patients with ASDH with GCS scores between 3 and 15 and in $65 \%-82 \%$ of those with GCS scores less than $10 .{ }^{[13]}$ We did not identify a correlation between sex, the cause of accident, hematoma thickness, comorbid hemorrhage, and additional pathological findings, similar to the findings of previous case series..$^{[4,8]}$ Moreover, we did not detect statistically significant differences in the mortality rate between the group of patients using blood-thinning medication and that of patients not using the medication. The lack of statistical significance can be explained by the small number of patients treated with anticoagulants and/or antiplatelet drugs.

The ICP monitoring is clinically useful after a secondary DC procedure for controlling the ICP and neurosurgical management of brain injury. However, it is still unclear whether ICP monitoring is practical after primary DCs. ${ }^{[23]}$ In their study, Huang et al. ${ }^{[24]}$ elucidated the relationship between the ICP monitoring and outcomes in patients undergoing primary DC for traumatic brain injury. They reported that neurological outcomes did not differ between the patient groups with ICP monitoring and without ICP monitoring. On the contrary, in a retrospective study by Picetti et al.," ${ }^{[2]}$ authors evaluated the clinical follow-up in 34 patients after primary DC following emergency hematoma evacuation. They noted that the knowledge of ICP values might be helpful in guiding therapy after primary DC. In our clinical practice, we did not perform ICP monitoring due to acute phase surgical operation and extensive DC and duroplasty procedures.

This study has some limitations. First, because it was a retrospective study, only eligible data in the charts were evaluated. Second, the study was performed at a single center. However, recording long-term outcomes is the strength of this study. In addition, our hospital is one of the well-equipped trauma centers in Istanbul, and it treats medically complicated cases with traumatic injuries.
In conclusion, our findings show that older age and lower GCS scores among patients with ASDH who underwent DC are associated with a high mortality rate in regression analyses. Although several studies have reported that DC is generally preferred in older patients with lower GCS scores, we suggest that the enlargement of DC be considered depending on the severity of cerebral edema to minimize complications regardless of the patient's age.

\section{Acknowledgments}

The authors thank Mr Mustafa Cem Ertem for his assistance with statistical analysis.

\section{Conflict of interest: None declared.}

\section{REFERENCES}

1. Karibe H, Hayashi T, Hirano T, Kameyama M, Nakagawa A, Tominaga T. Surgical management of traumatic acute subdural hematoma in adults: a review. Neurol Med Chir (Tokyo) 2014;54:887-94. [CrossRef]

2. Vilcinis R, Bunevicius A, Tamasauskas A. The Association of Surgical Method with Outcomes of Acute Subdural Hematoma Patients: Experience with 643 Consecutive Patients. World Neurosurg 2017;101:33542. [CrossRef]

3. Carney N, Totten AM, O'Reilly C, Ullman JS, Hawryluk GW, Bell MJ, et al. Guidelines for the Management of Severe Traumatic Brain Injury, Fourth Edition. Neurosurgery 2017;80:6-15.

4. Khalili H, Niakan A, Ghaffarpasand F, Kiani A, Behjat R. Outcome Determinants of Decompressive Craniectomy in Patients with Traumatic Brain Injury; A Single Center Experience from Southern Iran. Bull Emerg Trauma 2017;5:190-6.

5. Alvis-Miranda H, Castellar-Leones SM, Moscote-Salazar LR. Decompressive Craniectomy and Traumatic Brain Injury: A Review. Bull Emerg Trauma 2013;1:60-8.

6. Barthélemy EJ, Melis M, Gordon E, Ullman JS, Germano IM. Decompressive Craniectomy for Severe Traumatic Brain Injury: A Systematic Review. World Neurosurg 2016;88:411-20. [CrossRef]

7. Cooper DJ, Rosenfeld JV, Murray L, Arabi YM, Davies AR, D'Urso P, et al. Decompressive craniectomy in diffuse traumatic brain injury. $\mathrm{N}$ Engl J Med 2011;364:1493-502. [CrossRef]

8. Alagoz F, Yildirim AE, Sahinoglu M, Korkmaz M, Secer M, Celik H, et al. Traumatic Acute Subdural Hematomas: Analysis of Outcomes and Predictive Factors at a Single Center. Turk Neurosurg 2017;27:187-91.

9. Shen J, Pan JW, Fan ZX, Zhou YQ, Chen Z, Zhan RY. Surgery for contralateral acute epidural hematoma following acute subdural hematoma evacuation: five new cases and a short literature review. Acta Neurochir (Wien) 2013;155:335-41. [CrossRef]

10. Kinoshita T, Yoshiya K, Fujimoto Y, Kajikawa R, Kiguchi T, Hara M, et al. Decompressive Craniectomy in Conjunction With Evacuation of Intracranial Hemorrhagic Lesions Is Associated With Worse Outcomes in Elderly Patients With Traumatic Brain Injury: A Propensity Score Analysis. World Neurosurg 2016;89:187-92. [CrossRef]

11. Leitgeb J, Mauritz W, Brazinova A, Janciak I, Majdan M, Wilbacher I, et al. Outcome after severe brain trauma due to acute subdural hematoma. J Neurosurg 2012;117:324-33. [CrossRef]

12. Kaptanoğlu E, Solaroğlu I, Uçar MD, Okutan MO, Beşkonakli E, Taşkin Y. Acute subdural hematomas: surgical treatment. Retrospective analysis of 73 case. Ulus Travma Derg 2001;7:246-9. 
13. Brain Trauma Foundation; American Association of Neurological Surgeons; Congress of Neurological Surgeons. Guidelines for the management of severe traumatic brain injury. J Neurotrauma 2007;24 Suppl 1:S1-106.

14. Bullock MR, Chesnut R, Ghajar J, Gordon D, Hartl R, Newell DW, et al; Surgical Management of Traumatic Brain Injury Author Group. Surgical management of acute subdural hematomas. Neurosurgery 2006;58:S1624. [CrossRef]

15. Kotwica Z, Brzeziński J. Acute subdural haematoma in adults: an analysis of outcome in comatose patients. Acta Neurochir (Wien) 1993;121:95-9.

16. Bajsarowicz P, Prakash I, Lamoureux J, Saluja RS, Feyz M, Maleki M, et al. Nonsurgical acute traumatic subdural hematoma: what is the risk? J Neurosurg 2015;123:1176-83. [CrossRef]

17. Paci GM, Sise MJ, Sise CB, Sack DI, Shackford SR, Kureshi SA, et al. Preemptive craniectomy with craniotomy: what role in the management of severe traumatic brain injury? J Trauma 2009;67:531-6. [CrossRef]

18. Hanif S, Abodunde O, Ali Z, Pidgeon C. Age related outcome in acute subdural haematoma following traumatic head injury. Ir Med J 2009;102:255-7.

19. Koç RK, Akdemir H, Oktem IS, Meral M, Menkü A. Acute sub- dural hematoma: outcome and outcome prediction. Neurosurg Rev 1997;20:239-44. [CrossRef]

20. Honeybul S, Ho KM. Decompressive craniectomy for severe traumatic brain injury: the relationship between surgical complications and the prediction of an unfavourable outcome. Injury 2014;45:1332-9. [CrossRef]

21. Shabani S, Nguyen HS, Doan N, Baisden JL. Case Report and Review of Literature of Delayed Acute Subdural Hematoma. World Neurosurg 2016;96:66-71. [CrossRef]

22. Wilberger JE Jr, Harris M, Diamond DL. Acute subdural hematoma: morbidity, mortality, and operative timing. J Neurosurg 1991;74:212-8.

23. Demetriades AK. Intracranial pressure monitoring after primary decompressive craniectomy: is it useful? Acta Neurochir (Wien) 2017;159:6234. [CrossRef]

24. Huang YH, Ou CY. Prognostic Impact of Intracranial Pressure Monitoring After Primary Decompressive Craniectomy for Traumatic Brain Injury. World Neurosurg 2016;88:59-63. [CrossRef]

25. Picetti E, Caspani ML, Iaccarino C, Pastorello G, Salsi P, Viaroli E, et al. Intracranial pressure monitoring after primary decompressive craniectomy in traumatic brain injury: a clinical study. Acta Neurochir (Wien) 2017;159:615-22. [CrossRef]

\title{
ORIJIINAL ÇALIŞMA - ÖZET
}

\section{Akut subdural hematomda mortaliteye etki eden faktörler: Dekompresif kraniyektomi faydalı midır? \\ Dr. İlhan Yılmaz, ${ }^{1}$ Dr. Devrimsel Harika Ertem, ${ }^{2}$ Dr. Mustafa Kılıç, ${ }^{1}$ Dr. Kadir Altaş, ${ }^{1}$ Dr. Muyassar Mirhasilova, ${ }^{1}$ Dr. Burak Özdemir, ${ }^{1}$ Dr. Osman Tanrıverdi, ${ }^{3}$ Dr. Adem YıImaz ${ }^{1}$}

\begin{abstract}
'Sağlık Bilimleri Üniversitesi, Şișli Hamidiye Etfal Eğitim ve Araştırma Hastanesi, Nöroşirürji Kliniği, İstanbu ${ }^{2}$ Sağlık Bilimleri Üniversitesi, Şişli Hamidiye Etfal Eğitim ve Araştırma Hastanesi, Nöroloji Kliniği, İstanbul ${ }^{3}$ Sağlık Bilimleri Üniversitesi, Bakırköy Ruh ve Sinir Hastalıkları Hastanesi, Nöroşirurji Kliniği, İstanbul
\end{abstract}

AMAÇ: Hızı tanı ve agresif nöroşirürjik müdahalelere rağmen, akut subdural hematom (ASH), yüksek morbidite ve mortalite oranlarına neden olmaktadır. Kraniyotomi ve dekompresif kraniyektomi (DK) gibi cerrahi prosedürler etkili görünmemelerine rağmen, ASH'nin tedavisinde tercih edilen yaklaşım halen tartışmalıdır. Bu yazıda, DK uygulanan ASH hastalarında mortalite ile ilişkili faktörlerin değerlendirilmesi amaçlanmışır. GEREÇ VE YÖNTEM: 2012'den 2017'ye kadar 60 aylık bir dönemde ASH tanlı 93 olgunun mortalite, Glasgow Koma Skoru (GKS), demografik özellikleri, klinik ve radyolojik özellikleri değerlendirildi. Mortaliteyi öngörmede lojistik regresyon modelleri kullanıldı.

BULGULAR: Yaş ortalaması 59.82 19.49 (dağıım, 16-88) olan 65 erkek ve 28 kadın olgu alındı. On altı hasta (\% 7.2 ) ameliyatı takiben hayatını kaybetti. İleri yaş $(p=0.007)$ ve düşük $G K S$ skorları $(p=0.022)$ mortalite oranları üzerinde anlamlı bulundu. Ortalama hematom kalınlığı I5.46 \pm 5.73 $\mathrm{mm}$, orta hat kaymasının ortalaması $9.90 \pm 4.84 \mathrm{~mm}$ idi. ADSH hastalarında mortalite oranı aşıı orta hat kayması $(p=0.01 \mathrm{I}, r=0.262)$ ve yaş $(p=0.022, r=0.237)$ ile pozitif korelasyon gösterdi. Orta hat kayması $\geq 10 \mathrm{~mm}$ olan ve hematom kalınlığı $\geq 15 \mathrm{~mm}$ olan hastalarda mortalite oranı ile anlamlı bir ilişki vardı $(p=0.014, p=0.039)$. Ayrıca travma, subaraknoid, epidural ve intrakranial hemoraji komorbiditeleri, kompresyon kırıkları ve kontüzyonun etiyolojisi anlamlı olarak korelasyon göstermedi.

TARTIŞMA: Bulgularımız, DK'nin 65 yaş üzeri hastalarda ve GKS skoru <6 olanlarda daha yüksek mortalite oranları ile ilişkili olduğunu göstermektedir. Orta hat kaymasının $\geq 10 \mathrm{~mm}$ ve hematom kalınlığının $\geq 15 \mathrm{~mm}$ ve üzerinde olması mortalite ile anlamlı derecede ilişkilidir. Çalışmamız DK'nin ileri orta hat kaymasını önlemede yardımcı olabileceği ve kraniotomi ile kıyaslandığında daha düşük bir mortaliteyle birlikte olduğu sonucunu desteklemektedir.

Anahtar sözcükler: Akut subdural hematom; dekompresif kraniektomi; mortalite; sonuç.

Ulus Travma Acil Cerrahi Derg 2019;25(2):147-153 doi: 10.5505/tjtes.2018.48079 